Geology of the Papakaio District," by G. H. Uttley ; "A Comparison of the New Zealand and Western North American Cretaceous and Tertiary Formations," by P. G. Morgan. (October 17, 1917) "Natural Regions in New Zealand," by E. K. Lomas. (May 15, 1918) "The Geomorphology of the Coastal District of SouthWestern Wellington,"' by C. A. Cotton. (June 19, 1918) "Notes on the Post-Tertiary History of New Zealand," by J. Henderson. (July 17, 1918) "The Origin of the Amuri Limestone and Flint Beds," by J. Allan Thomson; "Notes on the Geology of Stephen Island," by J. Allan Thomson; "Permo-Carboniferous or Maitai Rocks of the East Coast of the South Island," by P. G. Morgan.

At the meeting a resolution was adopted expressing appreciation of the palmontological work of the late Mr. Henry Suter; and also a resolution expressing appreciation of the palæontological work of the late Dr. E. A. Newell Arber, in particular of his work on the Mesozoic floras of New Zealand.

\title{
OORRFSPONDEINCF.
}

THE GENESIS OF TUNGSTEN ORES.

Sir,-It is to be regretted that Mr. R. H. Rastall, when compiling his very useful summary of our present knowledge of the genesis, mode of occurrence, and mineral associations of the ores of tungsten, the first part of which appeared in the Geological Magazine for May, 1918, had not before him the results of later researches than those of Dr. Bleeck regarding the ore-deposits of the Tavoy district of Lower Burma, as his results have not been accepted entirely by later workers.

For the past three years a party of the Geological Survey of India has been working in Tavoy, and the district has also had the advantage of the presence of several enthusiastic private geologists. The Geological Survey party has examined most of the lodes which oceur, investigated their contents as carefully as possible, and mapped the boundaries of the granite and the sedimentary series into which it is intruded. Our results may be summarized briefly :-

1. Up to the present time not a single specimen of columbite has been found.

2 . Tourmaline does not occur in the ore mineral association, and is not a normal constituent of the granite. The occurrence of tourmaline pegmatites is known, but they are not associated with the orebearing zones and do not contain either wolfram or cassiterite.

3. Fluor spar is a widely distributed lode mineral, but it is only found in insignificant quantities.

4. Topaz is known to occur in one alluvial cassiterite deposit, and to-day, after three years of detailed field investigation together with petrological and chemical determirations in the laboratory, has only been found in situ once, in conjunction with fluor spar bordering a lode which contains relatively large quantities of pyrite, molybdenite, cassiterite, and very little wolfram. There are over one hundred producing mines in Taroy district alone, and the lodes examined must amount to many hundreds. 
Wolfram and cassiterite are nearly always associated together, though lodes containing one of these minerals, especially wolfram, to the entire exclusion of the other, are known. The mineral association in order of deposition is as follows: molybdenite, wolfram, cassiterite, natire bismuth, bismuthinite, chalcopyrite, arsenopyrite, pyrrhotite, galena, and blende. Scheelite also occurs in small quantities. In Mr. Rastall's classification of tungsten occurrences into paragenetic sub-types Burma should be associated with Queensland rather than with Etta Knob and Irigtut.

In a paper read before the fourth Indian Science Congress at Madras in January, 1916, of which only an incomplete summary has been published (see Journ. As. Soc. Bengal, N.s., vol. xiii, No. 2, pp. ccii-iii, 1917), I have suggested that the place of fluorine and boron may have been taken by sulphur and arsenic in the pneumatolytic stages of ore formation here. I am driven to this conclusion by the universal presence of sulphides, generally in the form of pyrite, in the lavoyan lodes and the relatire absence of minerals containing fluorine and boron.

Some of our lodes are pegmatites. Ther contain felspar as well as quartz. They have the composition, structure, texture, and other characteristic features of normal pegmatites, but they carry wolfram and cassiterite as well. I have suggested that others in which the pegmatitic origin is not so clear may represent a hydrothermal phase of pegmatite development resulting in the production of quartz with the ore minerals. There are cases here where true wolfram and cassiterite-bearing pegmatites pass in short distances along their strike directions into pure quartz veins with wolfram and tinstone.

I do not deny the part played br pneumatolrtic reactions as they are generally understood. I cannot account for the greisens which sometimes border the walls of lodes in granite and also carry valuable quantities of ore minerals by any other theory, but I doubt whether fluorine and boron played much part in the reactions.

It is pleasing to note that Mr. Rastall concludes that there is no real distinction between magmatic segregations and veins in this type of ore-deposit, for if it is correct to regard the pegmatite-aplite group of rocks as differentiation products of granites, it is reasonable to regard their metallic ores as segregations from acid magmas to the same extent.

The wolfram occurrences in other parts of Burma are not identical with those of Tavoy, though this district produces by far the greater proportion of Burma's output. Tourmaline is present in the Mergui lodes and also in those of the Thaton district. Beryl is a common mineral in the lodes of the Yamethin district.

Mr. Rastall has alluded to the widely scattered literature on the subject, and to his bibliography on this district the following published papers may be added: "Economic Geology of Tavoy," by J. Coggin Brown; "The Origin of Wolfram and a Preliminary Investigation as to its persistence at depth in the Tavoy District," by $\mathrm{Dr}$. W. R. Jones. Both these papers are published in a work entitled Lectures delivered at Tavoy under the auspices of the Mining Advisory Board, Superintendent Government Printing, Rangoon; 
1918. "The Disintegration of Wolfram," a letter published in the Mining and Scientific Press, San Francisco, September, 1917, by myself; The Ore Minerals of the Tavoy District, by J. Morrow Campbell, published privately, but available from Messrs. Rowe \& Co., Rangoon.

As far as I understand their published views. Dr. W. R. Jones supports the pneumatolytic theory of the origin of the deposits, while Mr. J. Morrow Campbell believes that highly siliceous water was the agent which leached tin and tungsten from the magma and at quite moderate temperatures deposited cassiterite, wolfram, and associated minerals in reins.

J. Coggin Brown,

Tavoy, Burma.

Assistant Superintendent, Geological Survey of India.

October 1, 1918.

\section{THE FAUNA AND FLORA OF THE GREAT ICE AGE.}

Srr,-The remains of the past fauna and flora have frequently been utilized in supporting the theory of an Ice Age. But little justice has been done to this subject, although it has been maintained by some authorities that the geological history of both animals and plants furnish strong evidence in favour of an Ice Age. In Sir Henry Howorth's series of instructive articles in the Geonogicat Magazine of August, September, and October last he emphasizes some features in the past and present marine fauna of the Baltic which deserve very careful consideration. His remarks about Yoldia and its distribution apply with equal force to dozens of other species of marine organisms. The argument that because a species now lives at a certain depth in the Arctic Ocean it must hare lived at the same depth during the Ice Age much further south is a fallacy, as Sir Henry How orth points out. Although some forms of animal and plant life readily adapt themselves to changes of temperature in the course of their migrations most of them require for their existence and welfare a uniform temperature. The conclusions arrived at by Sir Henry Howorth are based on the conditions which obtain almost everywhere near the coasts of Europe at the present day. We may observe Arctic species thriving at considerable depths, while Southern species inhabit the shallow water of the same area. In elucidating the geological history of the Baltic these conclusions, with which I entirely agree, are of the highest importance.

National Museum, Dublin.

R. F. SchaRfF.

November 23, 1918.

\section{OBITUARY. \\ JOHN DUER IRVING.}

BoRN AUgust 18, 1874.

DIED JULY 20, 1918.

John Doer Inving, the son of Professor R. D. Irving, of the University of Wisconsin, was educated at Columbia University, and 